\title{
EFFECT OF ADDITIVES ON THE COMPRESSIVE STRENGTH OF SLAG-BASED INORGANIC POLYMERS
}

\section{ZAHARAKI* \\ K. KOMNITSAS}

Received: 01/09/08

Accepted: 04/11/08

\author{
Department of Mineral Resources Engineering, \\ Technical University of Crete, \\ 73100, Hania, Greece
}

*to whom all correspondence should be addressed: e-mail: zaharaki@mred.tuc.gr

\begin{abstract}
The present paper aims to assess the effect of various additives on the compressive strength of inorganic polymers (geopolymers) synthesised using low Ca electric arc ferronickel slag and alkali activating solutions. The main operating parameters include pre-curing (48 hours), temperature $\left(40\right.$ to $80{ }^{\circ} \mathrm{C}$ ), heating time $(24$ or $48 \mathrm{~h}$ ) and aging period (7 days). Addition of kaolinite, pozzolan, fly ash, red mud or $\mathrm{CaO}$ in the initial mixture has a detrimental effect on the final compressive strength. Addition of pulverised silica sand improves strength slightly, whereas addition of commercial glass results in strength values exceeding $60 \mathrm{MPa}$. XRD analysis was carried out to identify new formed phases and the degree of amorphicity, while SEM and element mapping analysis were used to identify the morphology of the final products as well as to elucidate to a certain degree the mechanisms involved in inorganic polymer synthesis.
\end{abstract}

KEYWORDS: inorganic polymer, compressive strength, slag, glass.

\section{INTRODUCTION}

Alkali activated systems formed under low temperature and pressure and containing calcium silicate hydrated (CSH) and aluminosilicate phases, were first introduced by Glukhovsky (1965). Later, these products were called soil silicates while nowadays the most commonly used terms are inorganic polymers or geopolymers (Davidovits, 2005).

Inorganic polymers are similar to zeolites in chemical composition but they are characterised by an amorphous to semi-crystalline three-dimensional alumino-silicate microstructure (Davidovits, 1991; 1994). The exothermic process of inorganic polymer synthesis starts with the dissolution of $\mathrm{Si}$ and $\mathrm{Al}$ in alkaline solutions forming thus a $\mathrm{M}_{\mathrm{x}}\left(\mathrm{AlO}_{2}\right)_{\mathrm{y}}\left(\mathrm{SiO}_{2}\right)_{\mathrm{z}} \cdot \mathrm{nMOH} \cdot \mathrm{mH}_{2} \mathrm{O}$ gel $\left(\mathrm{M}: \mathrm{K}^{+}\right.$or $\mathrm{Na}^{+}$) that quickly hardens (Xu and Van Deventer, 2000; $\left.\mathrm{Xu}, 2001\right)$. Due to the complex nature of most raw materials present in the initial mixture, the exact mechanisms involved in synthesis of inorganic polymers need to be further elucidated; it is believed though that the main mechanisms are dissolution, transportation or orientation and polycondensation.

The structure and physical properties of inorganic polymers depend on several parameters such as particle size, thermal history, alkali metal and water content as well as degree of crystallinity (or amorphicity) (Van Jaarsveld et al., 2003). Depending on synthesis conditions, structural integrity and strength may be acquired in a relatively short time, even within $60 \mathrm{~min}$. The products are often characterised by excellent durability and chemical resistance as well as by a much smaller $\mathrm{CO}_{2}$ footprint compared to Portland cement (Duxson et al., 2007). Some inorganic polymers such as new special and blended cements, building materials and temperature stable resins are already used in industrial applications (Davidovits, 1988). Other environmentally oriented applications may include immobilisation of hazardous elements present in wastes, surface capping of waste dumps and stabilisation of tailing dams (Van Jaarsveld et al., 1999). 
Natural minerals (e.g. kaolinite, albite) as well as a number of mining and metallurgical wastes may be used during inorganic polymer synthesis. Various types of fly ashes have been extensively investigated for immobilisation of toxic metals (Krivenko and Skurchinskaya, 1991; Palomo et al., 1999; Van Jaarsveld et al., 1999; Bakharev, 2005). Alkali-activation of high calcium blast furnace slags has been also studied over the past years with promising results (Glukhovsky, 1994; Roy, 1999; Astutiningsih and Liu, 2005; Komnitsas et al., 2007; Van Deventer et al., 2007; Zhang et al., 2007). Additional research efforts are required though for the increase of the degree of utilisation of mining and metallurgical wastes and the production of inorganic polymers with advanced properties (Provis et al., 2005). When this technology overcomes several industrial barriers and becomes fully established it will definitely contribute to the sustainable development of the broader minerals sector (Komnitsas and Zaharaki, 2007).

The present experimental study aims to assess the effect of various additives, namely kaolinite, pozzolan, fly ash, red mud, $\mathrm{CaO}$, pulverised silica sand or commercial glass on the compressive strength of inorganic polymers synthesised using low $\mathrm{Ca}$ electric arc ferronickel slag and alkali activating solutions. XRD, SEM and element mapping analysis were used to identify new formed phases, the degree of amorphicity, the morphology of the final products and elucidate to a certain degree the mechanisms involved during inorganic polymer synthesis.

\section{MATERIALS AND METHODS}

The raw material used is electric arc furnace ferronickel slag obtained from LARCO S.A (Larymna plant) in Greece. The annual slag production is about 1,700,000 $t$ of which approximately 450,000 $\mathrm{t}$ are used in the cement industry. The disposal cost of the remaining quantities is estimated at $650,000 € /$ year. Slag is a brittle material and its grain size varies between $0.075 \mathrm{~mm}$ and $4 \mathrm{~mm}$. Slag was dried and crushed $\left(-120 \mu \mathrm{m}, \mathrm{d}_{50}:-12 \mu \mathrm{m}\right)$ using a FRITSCH pulveriser in order to increase surface area and improve the compressive strength of the produced inorganic polymers (Zaharaki, 2005; Zaharaki et al., 2006). Additives used include kaolinite (Fluka), $\mathrm{CaO}$ (Alfa Aesar), silica sand as well as pozzolan, fly ash, red mud and commercial glass. Particle size analysis of all raw materials used was determined using a laser analyser (Mastersizer S, Malvern Instruments).

Table 1 shows the chemical analysis of the slag and the additives used in the form of oxides and trace elements. Olivines (fayalite and forsterite), anorthite, quartz, tridymite, cristobalite, magnetite and chromite are the main mineralogical phases present in slag. It is estimated that the amorphous content exceeds $50 \%$.

Table 1. Chemical analysis and size distribution of ferronickel slag and additives

\begin{tabular}{lccccc}
\hline \multicolumn{1}{c}{$\%$} & Ferronickel slag & Pozzolan & Fly ash & Red mud & Commercial glass \\
\hline $\mathrm{Fe}_{2} \mathrm{O}_{3}$ & 43.83 & 1.09 & 5.60 & 45.48 & - \\
$\mathrm{SiO}_{2}$ & 32.74 & 72.22 & 33.40 & 6.96 & 74.00 \\
$\mathrm{Al}_{2} \mathrm{O}_{3}$ & 8.32 & 17.73 & 13.10 & 15.65 & 1.30 \\
$\mathrm{CaO}$ & 3.73 & 0.95 & 35.31 & 14.84 & 10.50 \\
$\mathrm{Cr}_{2} \mathrm{O}_{3}$ & 3.07 & - & - & - & - \\
$\mathrm{MgO}$ & 2.76 & 1.10 & 3.67 & - & - \\
$\mathrm{Mn}_{3} \mathrm{O}_{4}$ & 0.44 & 0.19 & 0.19 & - & - \\
$\mathrm{Na}_{2} \mathrm{O}$ & - & 3.30 & 0.46 & 3.26 & 13.00 \\
$\mathrm{~K}_{2} \mathrm{O}$ & - & 3.05 & 0.76 & - & - \\
$\mathrm{P}_{2} \mathrm{O}_{5}$ & - & 0.56 & - & - & - \\
$\mathrm{TiO}_{2}$ & - & 0.14 & 0.71 & 4.80 & - \\
$\mathrm{SO}_{3}$ & - & - & 6.58 & - & - \\
$\mathrm{S}$ & 0.18 & - & - & - & - \\
$\mathrm{C}$ & 0.11 & - & - & - & - \\
$\mathrm{Ni}$ & 0.10 & - & - & - & - \\
$\mathrm{Co}$ & 0.02 & - & - & - & - \\
\hline
\end{tabular}

Silica sand, purchased in a granular form $(-1+0.5 \mathrm{~mm})$, consists of quartz; it was pulverised prior to use $\left(-300 \mu \mathrm{m}, d_{50}:-13 \mu \mathrm{m}\right)$. Pozzolan $\left(-350 \mu \mathrm{m}, d_{50}:-25 \mu \mathrm{m}\right)$, was obtained from Milos 
island, Greece, is a very cheap material and when used in Portland cement concrete increases its long-term compressive strength. Fly ash $\left(-400 \mu \mathrm{m}, \mathrm{d}_{50}:-32 \mu \mathrm{m}\right)$ was obtained from Ptolemais, N.W. Greece, thermal power station and is classified according to ASTM as type $\mathrm{C}$; its main mineralogical phases are quartz $\mathrm{SiO}_{2}$, calcite $\mathrm{CaCO}_{3}$, anhydrite $\mathrm{CaSO}_{4}$, gehlenite $\mathrm{Ca}_{2}\left(\mathrm{Al}(\mathrm{AISi}) \mathrm{O}_{7}\right)$, albite $\mathrm{NaAlSi}_{3} \mathrm{O}_{8}$, lime $\mathrm{CaO}$ and portlandite $\mathrm{Ca}(\mathrm{OH})_{2}$. Red mud $(-76$ $\mu \mathrm{m}, \mathrm{d}_{50}:-4 \mu \mathrm{m}$ ) was obtained from "Aluminum of Greece" S.A. and consists of quartz $\mathrm{SiO}_{2}$, hematite $\mathrm{Fe}_{2} \mathrm{O}_{3}$, gibbsite $\mathrm{Al}(\mathrm{OH})_{3}$, diaspore $\mathrm{AIO}(\mathrm{OH})$, calcite $\mathrm{CaCO}_{3}$, cancrinite $\mathrm{Na}_{6} \mathrm{Ca}_{2} \mathrm{Al}_{6} \mathrm{Si}_{6} \mathrm{O}_{24}\left(\mathrm{CO}_{3}\right)_{2}$ and katoite $\mathrm{Ca}_{3} \mathrm{Al}_{2}\left(\mathrm{SiO}_{4}\right)(\mathrm{OH})_{8}$. Commercial glass is an amorphous material consisting mainly of silicon, calcium and sodium oxides; it was pulverised prior to use $\left(-350 \mu \mathrm{m}, \mathrm{d}_{50}:-23 \mu \mathrm{m}\right)$.

The activating solution was prepared by dissolving potassium hydroxide anhydrous pellets (ACS-ISO for analysis) in deionised water and mixing with sodium silicate solution (Merck, $\mathrm{Na}_{2} \mathrm{O}=7.5-8.5 \%, \mathrm{SiO}_{2}=25.5-28.5 \%$ ). Slag and additives were then slowly added into the solution and the resulting paste was well mixed. The wt $\%$ addition of slag and additives varies and depends on the reagents used in each case to produce a workable paste. Control specimens were prepared in each experimental series using only slag and activating solution; a typical composition is (\% w/w): slag $82 \%$, water $7 \%, \mathrm{KOH} 3 \%, \mathrm{Na}_{2} \mathrm{SiO}_{3} 8 \%$.

The cement like pulp was cast in high resistant plastic cubic moulds ( $5 \mathrm{~cm}$ each side), which were then vibrated for $5 \mathrm{~min}$ so that practically all air trapped within the reactive mass was removed. Pre-curing of the sealed moulds took place for 2 days at room temperature $\left(\sim 22{ }^{\circ} \mathrm{C}\right)$ in order to utilise the existing moisture of the paste and initiate inorganic polymer reactions enhancing thus strength development. If the paste is not pre-cured but heated immediately most of the water evaporates fast, cannot participate in reactions involved in strength development and the final strength acquired is in general low (Komnitsas et al., 2007; 2009).

The moulds were then placed into a laboratory oven (MMM $\mathrm{GmbH}$ ) and heated at the required temperature for a specific period. Aging took place under room temperature for 7 days in order to enhance the development of structural bonds. Compressive strength measurements of the produced inorganic polymers were carried out using an MTS 1600 load frame.

XRD analysis was performed by a Siemens D500 diffractometer using a Fe tube and a scanning range from $3^{\circ}$ to $70^{\circ} 2 \theta$, with a step $0.03^{\circ}$ and $4 \mathrm{sec} / \mathrm{step}$ measuring time. The qualitative analysis was carried out using the Diffrac ${ }_{\text {plus }}$ Software (Bruker AXS) and the PDF database. Imaging of the inorganic polymer microstructure was carried out using a JEOL JSM-5400 scanning electron microscope equipped with an Oxford energy dispersive X-ray spectrometer (EDS). Specimens were coated with carbon prior to analysis to increase conductivity of the surface.

\section{RESULTS AND DISCUSSION}

\subsection{Effect of additives}

In order to study the effect of kaolinite and pozzolan addition on the compressive strength of inorganic polymers, $5 \% \mathrm{w} / \mathrm{w}$ of each material was added in the initial mixture and the resulting products were heated at 40,60 and $80^{\circ} \mathrm{C}$ for 24 or 48 hours. Figure 1 shows the evolution of the compressive strength vs. temperature and heating time. It is seen that addition of kaolinite or pozzolan does not practically improve compressive strength. Addition of pozzolan results in a decrease of compressive strength by more than $50 \%$ compared to the control specimen over the temperature range studied; obtained strength varies between 12 and $20 \mathrm{MPa}$. On the other hand, addition of kaolinite results in higher compressive strength almost reaching at 80 ${ }^{\circ} \mathrm{C}$ the values obtained for the control specimen. Limited improvement is seen when duration of heating increases from 24 to 48 hours over the entire temperature range; this means that most inorganic polymer bonds are developed in a very short time. 


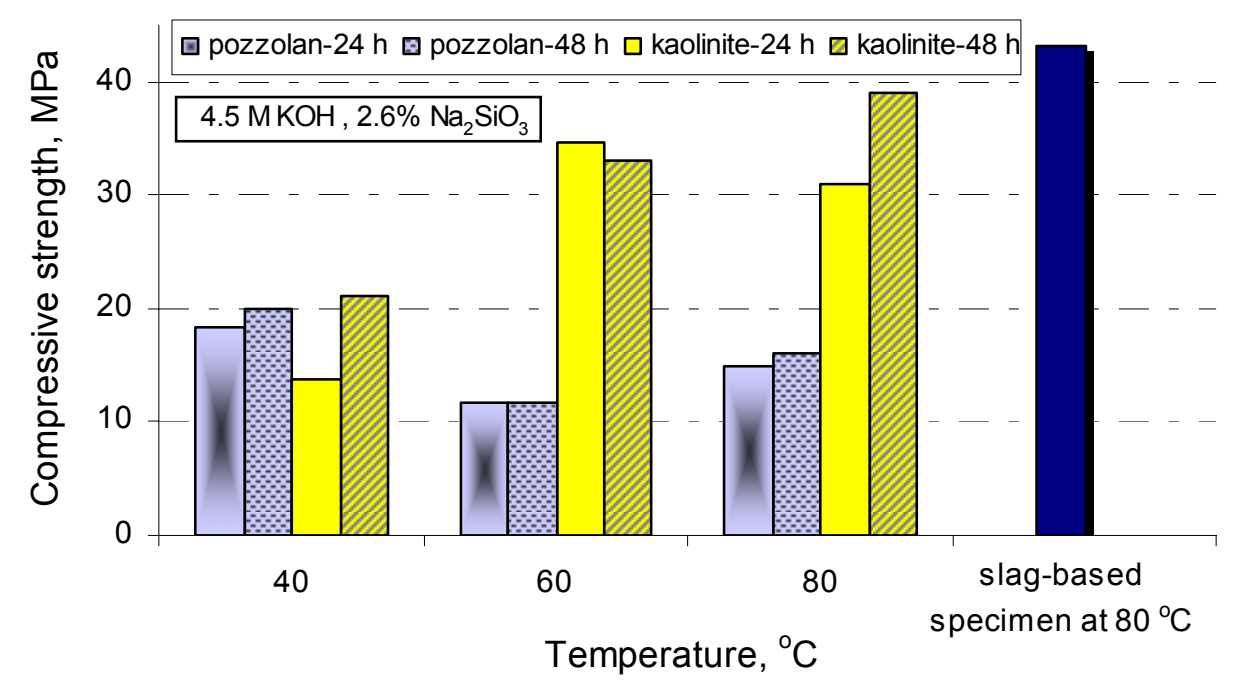

Figure 1. Evolution of the compressive strength vs. temperature and heating time in the presence of $5 \% \mathrm{w} / \mathrm{w}$ of pozzolan or kaolinite in the starting mixture

The effect of fly ash and red mud addition on the compressive strength is shown in Figure 2; these tests were carried out to explore the possibility of co-utilisation of mining and metallurgical wastes. It is seen from this figure that very low strength values are obtained in both cases when addition percentages vary between 20 and $50 \% \mathrm{w} / \mathrm{w}$. Slag as well as both additives used consist of various oxides exhibiting different degree of solubilisation when they react with the activating solution; as a result the number of $\mathrm{Si}$ and $\mathrm{Al}$ ions provided in the system cannot be easily assessed. The experimental results indicate that a part of these ions do not participate in reactions involved in inorganic polymer bond development and therefore limited strength is acquired.

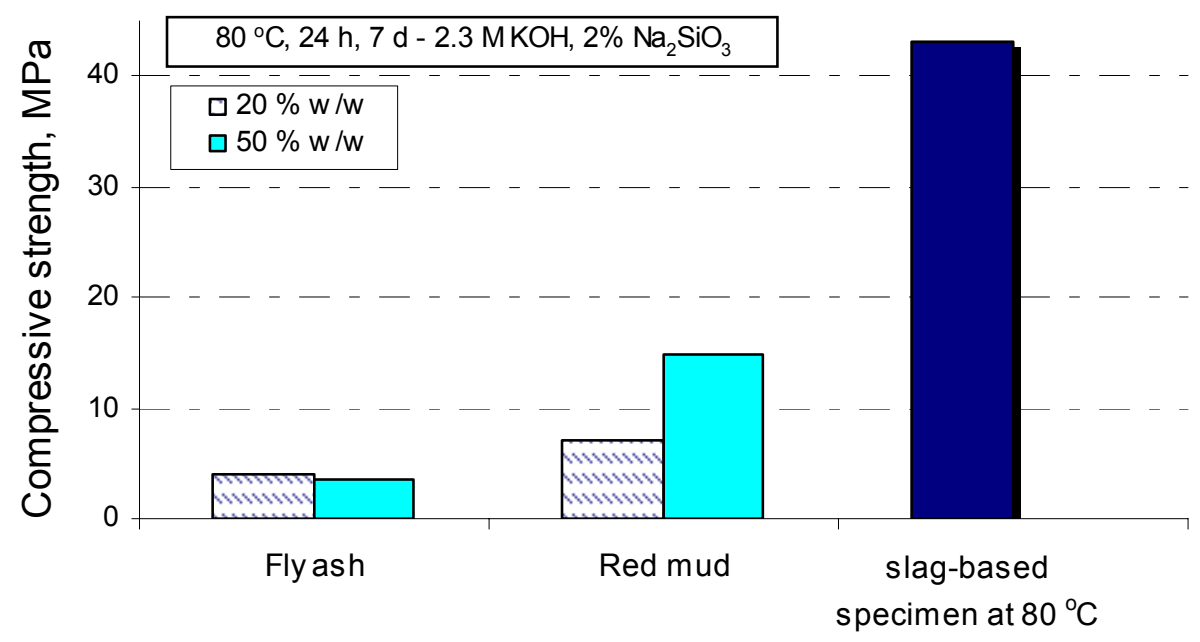

Figure 2. Effect of fly ash / red mud addition on the compressive strength

Figure 3 shows the effect of silica sand and $\mathrm{CaO}$ addition, varying between $5 \%$ and $20 \% \mathrm{w} / \mathrm{w}$, on the compressive strength. Silica sand addition improves in all cases the compressive strength that reaches almost $60 \mathrm{MPa}$ when the addition percentage is $5 \% \mathrm{w} / \mathrm{w}$. The compressive strength drops slightly when the percentage addition increases to $20 \% \mathrm{w} / \mathrm{w}$; this is probably due to the fact that the activating solution used is not sufficient to react with the increased quantity added and form strong bonds. The particle size of silica sand barely affects compressive strength; almost identical values were obtained when either coarse or pulverised silica sand was used (data not shown). On the other hand $\mathrm{CaO}$ addition results in low strength not exceeding $25 \mathrm{MPa}$; strength decreases in a linear manner when higher \% $\mathrm{CaO}$ is used. Similar results were reported in previous studies (Zaharaki et al., 2007, Yip et 
al., 2008; Komnitsas et al., 2009). An overdose of $\mathrm{CaO}$ binds almost all the available silica to form weak linear chains, therefore insufficient silica is left to nucleate the gel. In addition, part of the excess calcium may remain un-reacted; as a result the quantity of C-S-H gel produced is not sufficient and the inorganic polymer network is disrupted (Zaharaki et al., 2007; Yip et al., 2008). It is also probable that at high alkalinity, calcium forms precipitates rather than hydrated gels.

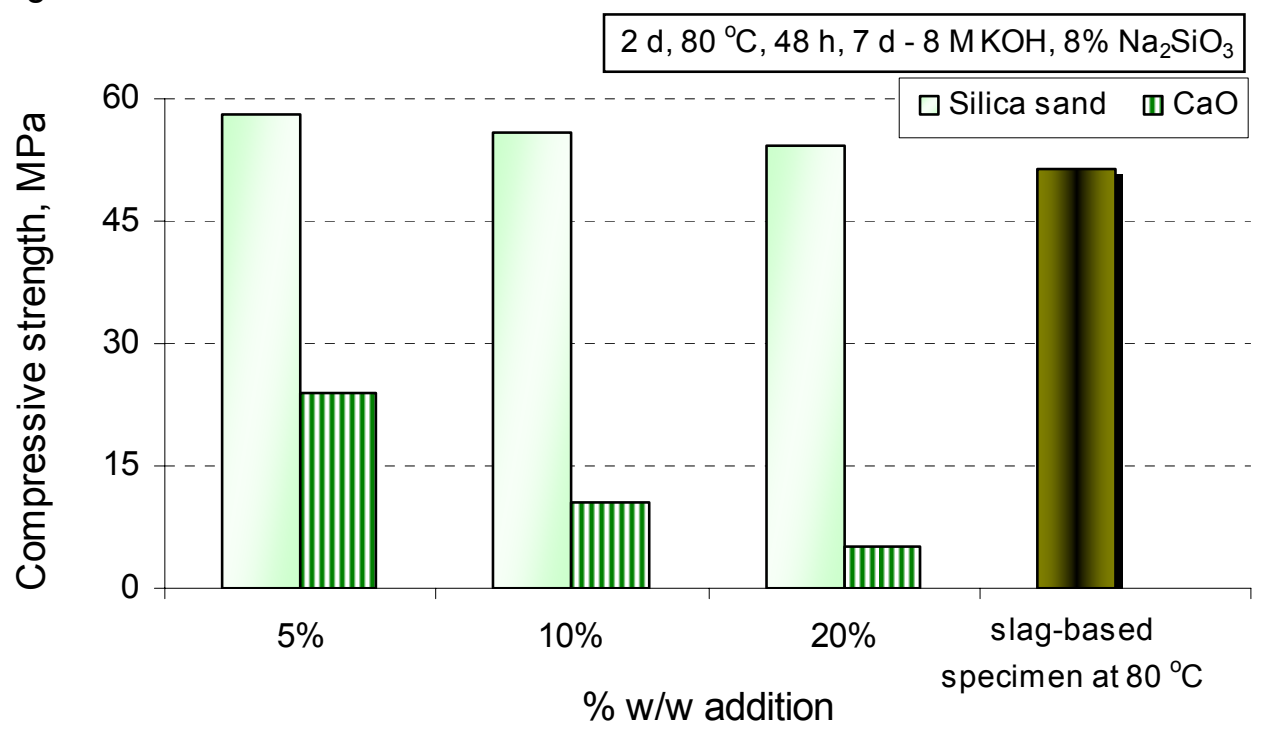

Figure 3. Effect of silica sand / $\mathrm{CaO}$ addition percentage $(\% \mathrm{w} / \mathrm{w})$ on the compressive strength

The high $\mathrm{Fe}_{2} \mathrm{O}_{3}$ content present in slag may also play an important role during synthesis, since it may react with the activating solution to form phases contributing to strength development (Zaharaki et al., 2007); this issue requires further investigation by using pure iron oxides. It should be underlined though that iron does not take part in the formation of inorganic polymer gel tetrahedral networks but may reduce the release of silica and alumina into the gel.

Figure 4 shows the evolution of the compressive strength of inorganic polymers vs. the $\% \mathrm{w} / \mathrm{w}$ glass addition; the compressive strength of pure slag and pure glass specimens (used as controls) is also seen. Addition of glass up to $50 \% \mathrm{w} / \mathrm{w}$ in the starting mixture does not practically improve strength which remains close to $52 \mathrm{MPa}$. When the percentage of glass increases to $90 \% \mathrm{w} / \mathrm{w}$ the acquired strength reaches $64 \mathrm{MPa}$. When only glass is used as raw material the compressive strength of the inorganic polymers produced is extremely high and reaches almost $125 \mathrm{MPa}$. It is believed that this is due to the homogeneity and the high amorphicity of the raw material used resulting thus in the development of extremely strong bonds, typical of three dimensional alumino-silicates.

The effect of $20 \% \mathrm{w} / \mathrm{w}$ kaolinite addition on the compressive strength of glass-based inorganic polymers synthesised at 40,60 and $80^{\circ} \mathrm{C}$ is seen in Figure 5; the strength of pure glass specimens, used as controls, is also presented. The experimental results show that addition of kaolinite results in much lower strength which barely exceeds $35 \mathrm{MPa}$ at $80^{\circ} \mathrm{C}$; at $40^{\circ} \mathrm{C}$ the obtained strength value is just $10 \mathrm{MPa}$. Kaolinite reacts only partially in the system under the conditions used, the available Si:Al ratio in the initial paste is affected and as a result the compressive strength acquired is relatively low; similar behavior is seen for slag-kaolinite inorganic polymers (Figure 1). On the other hand the effect of temperature is highly beneficial for pure glass inorganic polymers (Zaharaki, 2004; 2005); almost 30\% increase in the compressive strength is seen when temperature increases from 40 to $60{ }^{\circ} \mathrm{C}$, while an additional $50 \%$ increase is recorded when temperature increases further to $80^{\circ} \mathrm{C}$. 


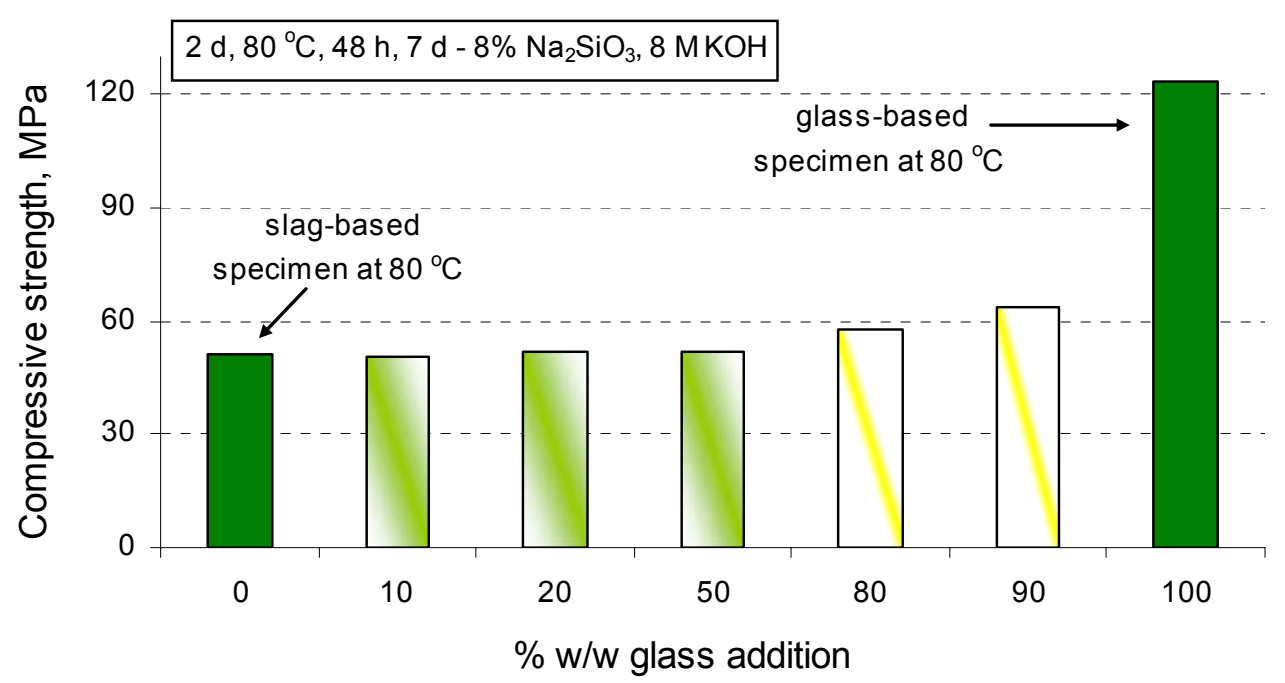

Figure 4. Evolution of compressive strength vs. the $\% \mathrm{w} / \mathrm{w}$ glass addition

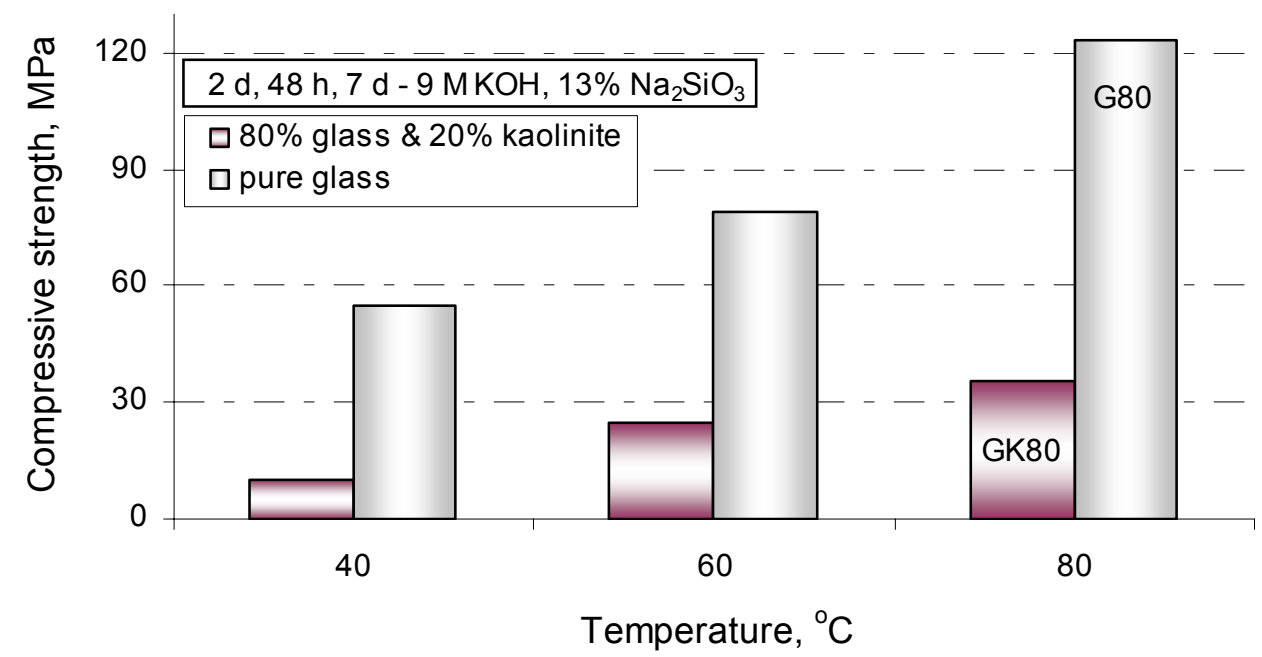

Figure 5. Effect of $20 \% \mathrm{w} / \mathrm{w}$ kaolinite addition on the compressive strength of glass-based inorganic polymers vs temperature

\subsection{XRD analysis}

Despite the substantial amorphous nature of ideal inorganic polymers, XRD is often used to identify new formed phases, define the extent to which starting materials have reacted and assess the degree of amorphicity of the final products. The XRD patterns (not shown) of inorganic polymers synthesised using slag-silica sand-kaolinite, slag-kaolinite and slagpozzolan, heated at $80{ }^{\circ} \mathrm{C}$ for 48 hours and aged under room temperature for 7 days, reveal the presence of quartz, magnetite and maghemite which were initially present in the slag. The presence of remaining kaolinite indicates that the initially used quantity has not fully reacted during inorganic polymer synthesis. Orthoclase, $\mathrm{K}_{0.58} \mathrm{Na}_{0.42} \mathrm{AlSi}_{3} \mathrm{O}_{8}$, is formed when raw materials react with sodium silicate and $\mathrm{KOH}$ activating solution. Calcite, $\mathrm{CaCO}_{3}$, is formed when calcium hydroxide reacts with atmospheric carbon dioxide.

X-ray patterns of raw glass $(G)$ as well as pure glass (G80) and glass-kaolinite (GK80) inorganic polymers synthesised at $80^{\circ} \mathrm{C}$ are seen in Figure 6 . The broad peaks seen between $17^{\circ}$ and $34^{\circ} 2 \theta$ in all patterns indicate a high degree of amorphicity. Pirssonite, $\mathrm{CaNa}_{2}\left(\mathrm{CO}_{3}\right)_{2}\left(\mathrm{H}_{2} \mathrm{O}\right)_{2}$, which is detected in $\mathrm{G} 80$ specimen, is an evaporite formed through atmospheric carbonation of glass which is characterised by high calcium content $(10.5 \%$ $\mathrm{w} / \mathrm{w})$. Phases such as kaolinite and quartz present in the raw materials can be detected also in GK80 inorganic polymer. New phases such as illite, $\mathrm{K}\left(\mathrm{Al}_{4} \mathrm{Si}_{2} \mathrm{O}_{9}(\mathrm{OH})_{3}\right)$, orthoclase, 
$\mathrm{K}_{0.58} \mathrm{Na}_{0.42} \mathrm{AlSi}_{3} \mathrm{O}_{8}$ and natrolite, $\mathrm{Na}_{2} \mathrm{Al}_{2} \mathrm{Si}_{3} \mathrm{O}_{10}$, are formed when kaolinite reacts with $\mathrm{KOH}$ and $\mathrm{Na}_{2} \mathrm{SiO}_{3}$.

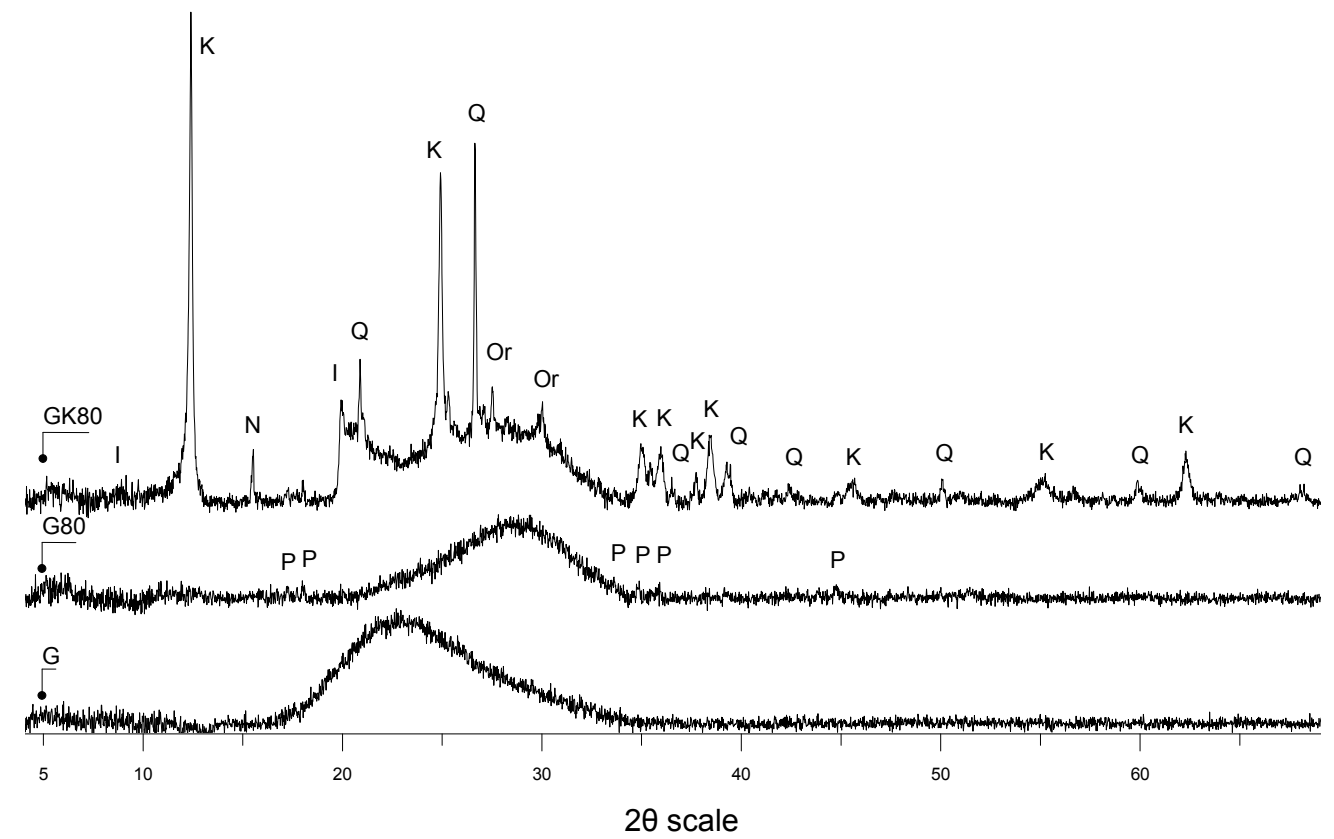

Figure 6. X-ray patterns of raw glass (G), pure glass inorganic polymer (G80) and glasskaolinite (GK80) inorganic polymer produced under various conditions (Q: Quartz, $\mathrm{K}$ : Kaolinite, I: Illite, Or: Orthoclase, N: Natrolite, P: Pirssonite)

\subsection{SEM analysis}

Slag-glass specimens exhibiting high compressive strength were examined under the microscope in order to identify their microstructure. A backscattered electron image (BSI) displaying the microstructure of a $50 \% \mathrm{w} / \mathrm{w}$ slag-glass inorganic polymer is shown in Figure 7. It is seen in this micrograph that the matrix is quite heterogenous; slag and glass grains are pointed out (slag grains are darker). The binder formed by the geopolymeric gel is seen between slag and glass grains.

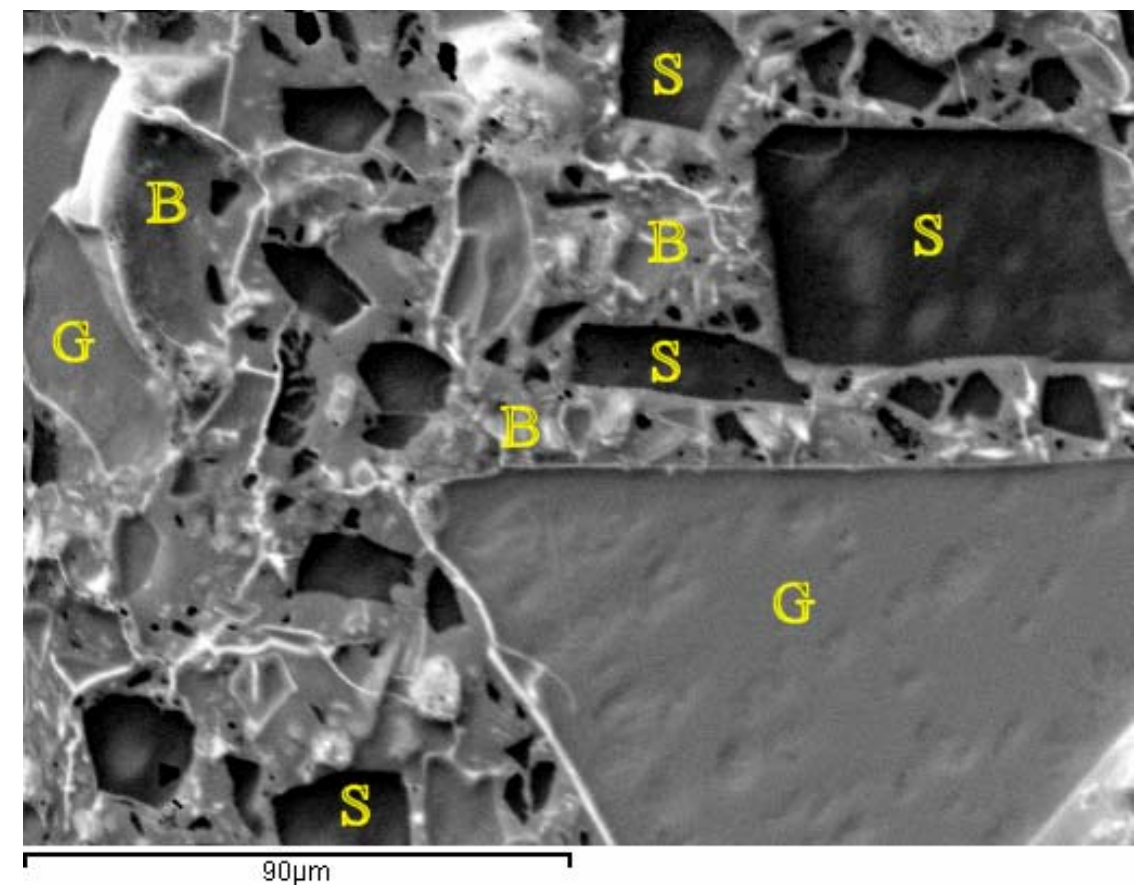

Figure 7. Backscattered image of slag-glass inorganic polymer

(S: slag grains, G: glass grains, B: binder) 
The element spectra for slag and glass grains as well as for the binder show that the ratio of $\mathrm{Si} / \mathrm{Al}$ in slag, which also contains calcium and chromium, is $\sim 2.5$. Glass grains consist mainly of silicon while some calcium and magnesium are also seen. The binder contains silicon and aluminum solubilised from the raw materials; silicon is also provided from the sodium silicate solution used during synthesis. The Si/Al ratio, which is affected by the potassium hydroxide concentration, is higher in the binder $(\sim 13)$ than the respective ratio in slag $(\sim 2.5)$ and lower than that in glass ( 21.5) (Schneider et al, 2001). Considering that $\mathrm{Si}$ and $\mathrm{Ca}$ are the main elements present in the binder (the content of $\mathrm{Na}$ and $\mathrm{Al}$ is much lower), it is believed that calcium silicate hydrates (CSH) are also formed (Zhang et al., 2007) or calcium may participate in the formation of Ca polysialate-(di)siloxo structures (Davidovits, 1988). It is also noted that the ratio of $\mathrm{Fe} / \mathrm{Cr}$ is almost identical in slag and the binder, 7.1 and 6.9 respectively, indicating that the solubilisation rate of iron and chromium phases present in the raw material is almost equal.

\section{CONCLUSIONS}

The present paper attempts to assess the effect of various additives on the compressive strength of inorganic polymers synthesised using low calcium electric arc ferronickel slag. Addition of kaolinite and pozzolan reduces to a lesser or higher degree the compressive strength over a temperature range varying between 40 and $80^{\circ} \mathrm{C}$. When fly ash or red mud is added a significant reduction of strength, up to $92 \%$, is seen; similar behaviour is seen when $\mathrm{CaO}$ is added. On the contrary, addition of pulverised silica sand increases slightly the compressive strength. Superior strength, reaching $123 \mathrm{MPa}$, is acquired for pure glass inorganic polymers; addition of kaolinite in this case results in much lower strength.

$\mathrm{XRD}$ is used to identify new formed phases, the degree of amorphicity and provide insights for the elucidation of mechanisms involved. Analysis of slag-based inorganic polymers reveals the presence of quartz, magnetite, maghemite and the formation of calcite. The presence of remaining kaolinite indicates that the initially used quantity has not fully reacted during synthesis. The morphology of slag-glass inorganic polymers was also investigated using backscattered SEM; unreacted particles present in the raw materials as well as calcium rich phases were identified.

Additional studies are required to elucidate inorganic polymer mechanisms, identify optimum synthesis conditions in each case, shed light on the degree, efficiency and chemical/physical nature of immobilisation of metals in the geopolymer matrix and assess the potential of this innovative technology for utilisation of mining and metallurgical wastes towards sustainable development of the broader minerals sector.

\section{ACKNOWLEDGEMENTS}

The financial support of the Research Committee of the Technical University of Crete for the basic research project "Elucidation of inorganic polymer mechanisms" is greatly acknowledged. The authors would also like to thank the assistance of the laboratories of Rock Mechanics and Ore Processing of the Department Mineral Resources Engineering of Technical University Crete, in various stages of this study, as well as LARCO S.A for providing the slag.

\section{REFERENCES}

Astutiningsih S. and Liu Y., (2005), Geopolymerisation of Australian slag with effective dissolution by the alkali, In: Proceedings of the World Congress Geopolymer, Davidovits, J. (Ed.), Saint Quentin, France, 69-73.

Bakharev T., (2005), Geopolymeric materials prepared using Class F fly ash and elevated temperature curing, Cement and Concrete Research, 35, 1224-1232.

Davidovits J., (1988), Geopolymer chemistry and properties, In: Proceedings of the 1st International Conference on Geopolymer '88, Davidovits, J. and Orlinski, J. (Eds.), vol. 1, Compiegne, France, 25-48.

Davidovits J., (1991), Geopolymers: Inorganic polymeric new materials, Journal of Thermal Analysis, 37, 1633-1656. 
Davidovits J., (1994), Geopolymers: Inorganic polymeric new materials, Journal of Materials Education, 16, 91-139.

Davidovits J., (2005), Geopolymer chemistry and sustainable Development. The Poly(sialate) terminology : a very useful and simple model for the promotion and understanding of greenchemistry, In: Proceedings of the World Congress Geopolymer, Davidovits, J. (Ed.), Saint Quentin, France, 9-15.

Duxson P., Provis J.L., Lukey G.C. and Van Deventer J.S.J., (2007), The role of inorganic polymer technology in the development of 'green concrete', Cement and Concrete Research, 37, 1590-1597.

Glukhovsky V.D., (1965), Soil silicates. Their properties, technology and manufacturing and fields of application, Doct. Tech. Sc. Degree Thesis, Civil Engineering Institute, Kiev, Ukraine.

Glukhovsky V.D., (1994), Ancient, modern and future concretes, In: Proceedings of the First International Conference on Alkaline Cements and Concretes, Krivenko P.V. (Ed.), Kiev, Ukraine, 1-9.

Komnitsas K. and Zaharaki D., (2007), Geopolymerisation: A review and prospects for the minerals industry, Minerals Engineering, 20, 1261-1277.

Komnitsas K., Zaharaki D. and Perdikatsis V., (2007), Geopolymerisation of low calcium ferronickel slags, Journal of Materials Science, 42, 3073-3082.

Komnitsas K., Zaharaki D. and Perdikatsis V. (2009), Effect of synthesis parameters on the compressive strength of low-calcium ferronickel slag inorganic polymers, Journal of Hazardous Materials, 161, 760-768.

Krivenko P. and Skurchinskaya J., (1991), In: Proceedings of the International Conference on the Utilization of Fly Ash and Other Coal Combustion By-products, Zhang-Zhao, G., Golden, D.M. and Chan, H.T. (Eds.), Shanghai, 64.1-64.7.

Palomo A., Grutzeck M.W. and Blanco M.T., (1999), Alkali-activated fly ashes - A cement for the future, Cement and Concrete Research, 29, 1323-1329.

Provis J.L., Lukey G.C. and Van Deventer J.S.J., (2005), Do geopolymers actually contain nanocrystalline zeolites? A reexamination of existing results, Chemistry of Materials, 17, 3075-3085.

Roy D., (1999), Alkali-activated cements-opportunities and challenges, Cement and Concrete Research, 29, 249-254.

Schneider J., Cincotto M.A. and Panepucci H. (2001), 29Si and 27Al high-resolution NMR characterization of calcium silicate hydrate phases in activated blast-furnace slag pastes, Cement and Concrete Research, 31, 993-1001.

Van Deventer J.S.J., Provis J.L., Duxson P. and Lukey G.C., (2007), Reaction mechanisms in the geopolymeric conversion of inorganic waste to useful products, Journal of Hazardous Materials, 139, 506-513.

Van Jaarsveld J.G.S., Van Deventer J.S.J. and Schwartzman A., (1999), The potential use of geopolymeric materials to immobilize toxic metals: part II. Material and leaching characteristics, Minerals Engineering, 12, 75-91.

Van Jaarsveld J.G.S., Van Deventer J.S.J. and Lukey G.C., (2003), The characterisation of source materials in fly ash-based geopolymers, Materials Letters, 57, 1272-1280.

Xu H., (2001), Geopolymerisation of aluminosilicate minerals, Ph.D. Thesis, Department of Chemical Engineering, University of Melbourne, Australia.

$\mathrm{Xu} \mathrm{H}$. and Van Deventer J.S.J., (2000), The geopolymerisation of aluminosilicate minerals, International Journal of Mineral Processing, 59, 247-266.

Yip C.K., Lukey G.C., Provis J.L. and Van Deventer J.S.J., (2008), Effect of calcium silicate sources on geopolymerisation, Cement and Concrete Research, 38, 554-564.

Zaharaki D., (2004), Synthesis and properties of geopolymers constructed from electric arc furnace ferronickel slag, Diploma Thesis, Department of Mineral Resources Engineering, Technical University Crete.

Zaharaki D., (2005), Optimisation of synthesis of geopolymers constructed from electric arc furnace ferronickel slag, M.Sc. Thesis, Department of Mineral Resources Engineering, Technical University Crete.

Zaharaki D., Komnitsas K. and Perdikatsis V., (2006), Factors affecting synthesis of ferronickel slag based geopolymers, Proceedings of the 2nd International Conference on Advances in 
Mineral Resources Management and Environmental Geotechnology, Agioutantis, Z. and Komnitsas K. (Eds.), Chania, Crete, Greece, 63-68.

Zaharaki D., Komnitsas K. and Perdikatsis V., (2007), Factors affecting the performance of wastebased geopolymers, In: Proceedings of the VI International Congress on Valorisation and recycling of Industrial Waste, L'Aquila, Italy, in CDROM.

Zhang Y., Sun W., Chen Q. and Chen L., (2007), Synthesis and heavy metal immobilization behaviors of slag based geopolymers, Journal of Hazardous Materials, 143, 206-213. 